BMJ Open

Sport \&

Exercise

Medicine

\section{Lay of the land: narrative synthesis of tackle research in rugby union and rugby sevens}

To cite: Burger N, Lambert M, Hendricks S. Lay of the land: narrative synthesis of tackle research in rugby union and rugby sevens. BMJ Open Sport \& Exercise Medicine 2020;6:e000645. doi:10.1136/ bmjsem-2019-000645

- Additional material is published online only. To view, please visit the journal online (http://dx.doi.org/10.1136/ bmjsem-2019-000645).

Accepted 22 March 2020

Check for updates

(c) Author(s) (or their employer(s)) 2020. Re-use permitted under CC BY-NC. No commercial re-use. See rights and permissions. Published by BMJ.

${ }^{1}$ Division of Exercise Science and Sports Medicine,

Department of Human Biology, Faculty of Health Sciences, University of Cape Town, Cape Town, Western Cape, South Africa

${ }^{2}$ Department of Public and Occupational Health and the EMGO Institute for Health and Care Research, VU University Medical Center, Vrije Universiteit Amsterdam, Amsterdam, The Netherlands

${ }^{3}$ Institute for Sport, Physical Activity and Leisure, Centre for Sport Performance, School of Sport, Fairfax Hall, Headingley Campus, Leeds Beckett University, Leeds, UK

Correspondence to Dr Sharief Hendricks; sharief.hendricks01@gmail.com

\section{ABSTRACT}

Objectives The purpose of this review was to synthesise both injury prevention and performance tackle-related research to provide rugby stakeholders with information on tackle injury epidemiology, including tackle injury risk factors and performance determinants, and to discuss potential preventative measures.

Design Systematic review and narrative synthesis. Data sources PubMed, Scopus and Web of Science. Eligibility criteria Limited to peer-reviewed Englishonly publications between January 1995 and October 2018.

Results A total of 317 studies were identified, with 177 in rugby union and 13 were in rugby sevens. The tackle accounted for more than $50 \%$ of all injuries in rugby union and rugby sevens, both at the professional level and at the lower levels, with the rate of tackle injuries higher at the professional level (mean 32/1000 player-hours) compared with the lower levels (mean 17/1000 player-hours). A player's tackle actions and technical ability were identified as major risk factors for injury and a key determinant of performance.

Summary/conclusion Evidence-based education, progressive tackle technique training with a high potential to transfer and law changes have been proposed as key modifiers of player tackle actions and technical ability. Conceivably, all three modifiers working in unison (as opposed to separately) will have a higher potential at reducing tackle injury risk while enhancing performance. With the guidance of tackle injury and performance studies, as well as stakeholder engagement, experiential and explorative tackle research has the potential to inspire innovative injury prevention and performance strategies.

\section{INTRODUCTION}

The physical and dynamic nature of rugby union and rugby sevens expose players to high risk of injury. The majority of injuries in these rugby codes, at all levels, occur during the contact events: the tackle, ruck, maul, line-out and scrums. ${ }^{1-4}$ The tackle is the contact event that has the highest injury incidence (injuries per 1000 player-hours), while the ruck and scrum have the second and third highest injury incidences, respectively. ${ }^{1-4}$ Also, while the majority of spinal cord injuries occur in the scrum, the tackle

\section{What is known}

- The physical and dynamic nature of rugby union and rugby sevens exposes players to high risk of injury.

- The tackle is the contact event that has the highest injury incidence.

- To effectively reduce the risk of injury and optimise performance, it is recommended a sport injury prevention or sport performance process model be followed.

\section{What this study adds}

Tackle injury rates are higher at the professional level compared with the lower levels.

- Tackle injury frequencies are similar between the ball carrier and tackler.

- A major risk factor for tackle injury and a key determinant of tackle performance is the player's technical ability.

- A player's technical ability can be improved through boosting coaching competencies. An example of such a coaching competency is how to monitor and progress tackle training to ensure optimum transfer to matches.

has the highest incidence for the most severe injuries. ${ }^{5}$ During the tackle, both the player in possession of the ball (ball carrier) and the player(s) attempting to contest the ball and territory (tacklers) are at risk of injury, ${ }^{6-9}$ although the mechanisms of injury may differ. $^{1011}$ Although the tackle is a high-injury risk contest, the ability to repeatedly win the contest is also a key performance indicator, with successful teams winning more tackles. ${ }^{12}$

To effectively reduce the risk of injury and optimise performance, it is recommended a sport injury prevention or sport performance process model such as the Translating Research into Injury Prevention Practice (TRIPP) model $^{13}$ (involving six stages) or the Applied Research Model for the Sport Sciences $^{14}$ (involving eight stages) be followed. These models outline a sequence of stages that need to be completed to ensure 
the uptake and sustainability of an injury prevention or performance initiative in the 'real world'. ${ }^{13}$ The first stage proposes establishing the extent of the injury problem through injury surveillance studies. Thereafter, the aim is to understand why and how these injuries occur, that is, identifying injury risk factors (stage 2). Stage 3 seeks to develop potential preventive measures for testing in ideal or controlled conditions (stage 4). Stage 5 aims to understand the implementation context, and the final stage (stage 6) monitors the effectiveness of the preventive measure in the real world.

Owing to the high risk of injury and performance demands, the tackle has been a research focus within rugby compared with other contact events. ${ }^{15}$ Seemingly, each of these studies have contributed to a stage in the injury prevention or performance process models. However, these studies have not been consolidated to determine the state of tackle-related research at each stage for both injury prevention and performance. For instance, while systematic reviews on injury rates in rugby union and rugby sevens have been published ${ }^{1-4}$ to address stage 1 of injury prevention models, and despite knowing the high incidence of tackle injury, no review to date has synthesised tackle injury frequencies and rates by playing levels and competition, and by role (ball carrier or tackler). Therefore, using the first three stages of the TRIPP mode ${ }^{13}$ as a guide, the purpose of this review was to consolidate both injury prevention and performance tackle-related research. The intention of this review was to synthesise both injury prevention and performance tackle-related research to provide rugby stakeholders with information on tackle injury epidemiology, including tackle injury risk factors and performance determinants, and to discuss measures that may improve tackle performance and reduce the risk of tackle injuries.

\section{METHODS}

A narrative synthesis format was chosen to review and synthesise the pool of literature. A narrative synthesis is an 'approach to the systematic review and synthesis of findings from multiple studies that relies primarily on the use of words and texts to summarise and explain the finding of the synthesis'. ${ }^{16}$ Narrative syntheses can be used to review and assess quantitative and qualitative data and, in contrast to 'narrative reviews' and 'evidence syntheses', involve a systematic and predefined search strategy with a focus on producing a more textual synthesis versus other types of systematic reviews such as quantitative metaanalyses.

\section{Search strategy}

A search was conducted for published studies that reported on tackle-specific factors in rugby union and rugby sevens (rugby league studies were included in the search but removed at the final stage of the selection process). Three electronic databases (PubMed, Scopus and Web of Science) were searched using the keyword combinations 'rugby' AND 'contact', 'rugby'
AND 'tackle', and 'rugby' AND ‘union' OR 'league' OR 'sevens' AND 'injur*'.

\section{Eligibility criteria}

The search was limited to peer-reviewed English-only publications between January 1995 (the advent of professionalism in rugby union) and October 2018. Articles that involved quantitative data on rugby union or rugby sevens (including all ages and levels of play, and male and female players) were included. Only studies that included tackle-related testing protocols and match or training data (pertaining to tacklers and/or ball carriers) were included. The studies had to clearly define the tackle or ball carry as part of their analysis and not group the tackle into general contact/collision data.

Overall and/or time-loss tackle injury rates (only studies reporting number of injuries per 1000 exposure) and frequencies (percentages) were tabulated according to rugby code and level of play (tables 1-3). A time-loss injury was defined as an injury that resulted in a player being absent from normal match/training/ recreational activities for more than 24 hours or 7 days (depending on the specific study's definition) after the incident. Medical attention injuries were injuries that required treatment from a doctor/healthcare professional but resulted in no time away from normal match/ training/recreational activities. Overall injuries included both medical attention and time-loss injury events. Injury case studies specific to tackle events were also reviewed (see online supplementary appendix 1 ). Overall tackle numbers and rates (only studies reporting total number of tackles per match, and/or number of tackles per game or per minute) were tabulated in tables 4 and 5 . Narrative literature reviews, systematic reviews, meta-analyses, editorials, journal letters, book chapters, conference proceedings, discussions and qualitative research studies were excluded from the analysis. All other quantitative study types and case studies were accepted for review.

\section{Screening process}

A five-step approach was followed to identify the final group of articles that would eventually be included in the final review (figure 1). Two authors (NB and $\mathrm{SH}$ ) independently screened the titles using the eligibility criteria. The reliability of the authors was assessed by comparing the results of the title-screening process. Disparities in the results were discussed and resolved by the authors. $\mathrm{NB}$ continued the screening process of the abstracts and full-text articles. The articles were excluded at each step if they met the exclusion criteria or did not meet the inclusion criteria.

\section{Data interpretation}

Only the main findings (relating to tackle events) from each study were presented in this review. Confidence intervals $(90 \%$ or $95 \%$ CIs) and standard deviations $( \pm$ SDs) were provided in the tables, depending on their availability. All values and percentages were rounded off 
Table 1 Tackle-related injury frequencies and rates in professional rugby union

\begin{tabular}{lllll}
\hline Study & Cohort & Injury definition & Injury frequency & Injury rate \\
\hline $\begin{array}{l}\text { Jakoet and } \\
\text { Noakes }^{145}\end{array}$ & 1995 RWC teams & $\begin{array}{l}\text { Overall and time- } \\
\text { loss (>1 day) }\end{array}$ & $\begin{array}{l}56 \%(29 \% \text { tackled, 27\% } \\
\text { tackling) }\end{array}$ & N/A \\
Targett $^{146}$ & Super 12 team & $\begin{array}{l}\text { Time-loss (>2 } \\
\text { training sessions, } \\
>1 \text { match) }\end{array}$ & $46 \%$ & N/A \\
& & & &
\end{tabular}

\begin{tabular}{llll} 
Doyle and George $^{147}$ & $\begin{array}{l}\text { England Women's } \\
\text { team }\end{array}$ & $\begin{array}{l}\text { Overall and time- } \\
\text { loss (>1 day) }\end{array}$ & $30 \%$ tackling \\
\hline Best et a $^{23}$ & 2003 RWC teams & $\begin{array}{l}\text { Overall and time- } \\
\text { loss (>1 day) }\end{array}$ & $\begin{array}{l}\text { 40\% (19\% tackled, 21\% } \\
\text { tackling) }\end{array}$
\end{tabular}

N/A

$38.9 / 1000$ hours (18.7/1000 hours tackled [95\% Cl 12.6 to 24.7$]$; $20.2 / 1000$ hours tackling $[95 \% \mathrm{Cl}$ 13.9 to 26.5$]$ )

\begin{tabular}{|c|c|c|c|}
\hline Brooks et $a l^{148}$ & $\begin{array}{l}\text { England } 2003 \text { RWC } \\
\text { team }\end{array}$ & Time-loss (>1 day) & $\begin{array}{l}36 \%(23 \% \text { tackled, } 13 \% \\
\text { tackling) }\end{array}$ \\
\hline Holtzhausen et al ${ }^{149}$ & $\begin{array}{l}\text { Super } 12 \text { South } \\
\text { African teams }\end{array}$ & $\begin{array}{l}\text { Time-loss ( }>1 \text { day or } \\
\text { special treatment) }\end{array}$ & $\begin{array}{l}61 \%(46 \% \text { tackled, } 15 \% \\
\text { tackling) }\end{array}$ \\
\hline Fuller et $\left.a\right|^{20}$ & $\begin{array}{l}\text { English Premiership } \\
\text { teams }\end{array}$ & Time-loss (>1 day) & $63 \%$ \\
\hline Fuller et $a l^{24}$ & 2007 RWC teams & Time-loss (>1 day) & N/A \\
\hline
\end{tabular}

\begin{tabular}{|c|c|c|c|c|}
\hline $\begin{array}{l}\text { Quarrie and } \\
\text { Hopkins }^{10}\end{array}$ & $\begin{array}{l}\text { Professional New } \\
\text { Zealand men's } \\
\text { teams }\end{array}$ & $\begin{array}{l}\text { Overall and time- } \\
\text { loss (>1 day) }\end{array}$ & N/A & $\begin{array}{l}12.2 / 1000 \text { hours }(5.8 / 1000 \text { hours } \\
\text { tackled }[90 \% \mathrm{Cl} 4.9 \text { to } 6.8] \text {; } \\
6.4 / 1000 \text { hours tackling }[90 \% \mathrm{Cl} \\
5.5 \text { to } 7.5])\end{array}$ \\
\hline Fuller et al ${ }^{151}$ & Super 14 teams & $\begin{array}{l}\text { Overall and time- } \\
\text { loss ( }>1 \text { day) }\end{array}$ & $\begin{array}{l}68 \%(41 \% \text { tackled } \\
\text { [95\% Cl } 35.5 \text { to } 47.2] ; \\
27 \% \text { tackling }[95 \% \mathrm{Cl} 21.5 \\
\text { to } 32])\end{array}$ & $\mathrm{N} / \mathrm{A}$ \\
\hline Fuller et al ${ }^{151}$ & $\begin{array}{l}\text { Vodacom Cup } \\
\text { teams }\end{array}$ & $\begin{array}{l}\text { Overall and time- } \\
\text { loss ( }>1 \text { day) }\end{array}$ & $\begin{array}{l}64 \%(33 \% \text { tackled } \\
\text { [95\% } \mathrm{Cl} 21.3 \text { to } 44.3] \\
\text { tackling } 31 \%[95 \% \mathrm{Cl} \\
19.9 \text { to } 42.6])\end{array}$ & $\mathrm{N} / \mathrm{A}$ \\
\hline Fuller et $\left.a\right|^{25}$ & 2011 RWC teams & Time-loss (>1 day) & $44 \%$ & $\begin{array}{l}40.1 / 1000 \text { hours }(21.9 / 1000 \text { hours } \\
\text { tackled }[95 \% \mathrm{Cl} 16.2 \text { to } 29.6] ; \\
18.2 / 1000 \text { hours tackling }[95 \% \mathrm{Cl} \\
13.1 \text { to } 25.4])\end{array}$ \\
\hline Schwellnus et $a l^{8}$ & $\begin{array}{l}\text { Super Rugby South } \\
\text { African teams }\end{array}$ & Time-loss (>1 day) & $\begin{array}{l}49 \% \text { ( } 23 \% \text { tackled, } 26 \% \\
\text { tackling) }\end{array}$ & N/A \\
\hline Fuller et $\left.a\right|^{26}$ & 2015 RWC teams & Time-loss (>1 day) & $\begin{array}{l}46 \%(25 \% \text { tackled } \\
\text { [95\% Cl } 18.2 \text { to } 31.2] ; \\
21 \% \text { tackling }[95 \% \mathrm{Cl} 15.0 \\
\text { to } 27.3])\end{array}$ & $\mathrm{N} / \mathrm{A}$ \\
\hline
\end{tabular}

Continued 
Table 1 Continued

\begin{tabular}{|c|c|c|c|c|}
\hline Study & Cohort & Injury definition & Injury frequency & Injury rate \\
\hline Ranson et $a l^{51}$ & UK club teams & Time-loss (>1 day) & $\mathrm{N} / \mathrm{A}$ & $\begin{array}{l}39.7 / 1000 \text { hours }(17.7 / 1000 \text { hours } \\
\text { tackled [ } 90 \% \mathrm{Cl} 14.5 \text { to } 21.5] \text {; } \\
22 / 1000 \text { tackling }[90 \% \mathrm{Cl} 18.4 \text { to } \\
26.2])\end{array}$ \\
\hline
\end{tabular}

N/A, not applicable; RWC, Rugby World Cup.

to a maximum of two decimal places where necessary. Results are organised according to the first three stages of the TRIPP model.

\section{RESULTS}

\section{Injury epidemiology and tackle frequencies}

General rugby union and sevens injury studies provided details pertaining to one or more tackle-related factors, including but not limited to injury rates, player injured (ie, ball carrier or tackler), player position (eg, forward or back), injury location (eg, head/neck, lower-limb or upper-limb), injury type/diagnosis (eg, concussion, fracture or bruise/contusion), tackle direction (eg, front-on or from behind) and player running speed prior to injury. ${ }^{6-11} 18-52$ The tackle consistently accounted for more than $50 \%$ of all injuries in rugby union and rugby sevens, both at the professional level and at the lower levels. The rate of tackle injuries are higher at the professional level (mean 32/1000 player-hours) compared with the lower levels (mean 17/1000 player-hours). At all levels, the frequency of injury between the ball carrier and tackler were not largely dissimilar.

Certain studies also focused on niche areas including head injuries and concussions, ${ }^{31} 40$ 53-70 spinal and neck injuries, ${ }^{71-79}$ shoulder injuries, ${ }^{34}{ }^{80-88}$ knee and ankle injuries ${ }^{89-93}$ and the influence of tackle technique on injuries. ${ }^{61} 64656994-96$ Overall and time-loss injury frequencies and rates for rugby union (tables 1 and 2) and sevens (table 3) were tabulated (all injury types included). Tackle-related injury case studies were also summarised for all levels of rugby union and sevens from 1995 to 2018 (see online supplementary appendix 1 ).

The total number of tackles per match and tackle rates (tackles per game or per minute) for all levels of play for rugby union and sevens are summarised in tables 4 and 5 , respectively. Successful and unsuccessful tackles were also included.

\section{Injury risk factors and performance determinants}

In matches, proper contact technique during the tackle, for both the ball carrier and tackler, has been identified as a key injury risk factor and performance determinant. ${ }^{6164656994-96}$ For example, ball carrier and tacklers that fail to 'leg drive' after contact have a higher risk of injury and a reduced chance of winning the tackle. ${ }^{56949597}$ In another example, ball carriers fending the tackler on contact have a reduced risk of injury and are more likely to offload or break the tackle. ${ }^{4898}$ Not surprisingly, high, dangerous and illegal tackles are also a major risk factor for tackle injuries. A match contextual factor that has also been identified as a risk factor for injury is match quarter. Tackle injuries are reported to occur more frequently during the latter stages of matches, ${ }^{15} 16$ which are attributed to a decrease in tackle technique. The physical and physiological demands of the tackle during matches, such as tackle velocity and muscle damage, have also been reported. ${ }^{99-123}$

Players' and coaches' knowledge, attitudes and behaviours pertaining to the tackle have been studied, including risk factors for injury and determinants of performance, both in training and matches. ${ }^{68}{ }^{124-130}$ For instance, players who rated tackle training to prevent injuries important (player attitude) and who spent more time on technique training to prevent injuries (player behaviour) reported safer behaviours for the tackle during matches. Also, coaches seem to be aware of the risk of injury in the tackle and the importance of coaching of proper technique. ${ }^{131}$ However, this positive knowledge and attitudes from the coaches did not transfer into tackle training (coach behaviour).

\section{Studying the tackle in controlled settings}

Within lab settings, the physiological and biomechanical loads of the tackle have been studied..$^{99101-113}$ These studies suggest that the movement patterns and the production of force are weaker on the non-dominant shoulder. ${ }^{103} 117$ For example, Seminati et al reported a $13 \%$ higher impact force from the dominant shoulder. ${ }^{132}$ Players seem to have poorer shoulder positional sense of their non-dominant shoulder while tackling ${ }^{133}$ and adopt a more passive biomechanical strategy to generate the drive needed to stop a ball carrier. ${ }^{132}$ As such, tackles on the dominant shoulder produce higher impact forces on contact, whereas the non-dominant shoulder produces force over longer durations. ${ }^{132}$ In addition, tackles on the non-dominant shoulder were characterised by less control of head movement, which had a more flexed and laterally bent position compared with tackles on the dominant shoulder. ${ }^{132}$

\section{DISCUSSION}

It is well established that a player's tackle actions and technical ability are major risk factors for injury and key determinants of performance. ${ }^{61646569}$ 94-96 The question is how can we modify player action and improve tackle technique? One answer to this question is player, coach 
Table 2 Tackle-related injury frequencies and rates in semiprofessional, amateur and youth rugby union

\begin{tabular}{|c|c|c|c|c|}
\hline Study & Cohort & $\begin{array}{l}\text { Injury } \\
\text { definition }\end{array}$ & Injury frequency & Injury rate \\
\hline $\begin{array}{l}\text { Comstock and } \\
\text { Fields }^{154}\end{array}$ & USA women's teams & $\begin{array}{l}\text { Overall and } \\
\text { time-loss ( }>7 \\
\text { days) }\end{array}$ & $\begin{array}{l}58 \%(30 \% \text { tackled, } 28 \% \\
\text { tackling) }\end{array}$ & N/A \\
\hline Collins et $a l^{31}$ & $\begin{array}{l}\text { Girls' US high school club } \\
\text { teams }\end{array}$ & $\begin{array}{l}\text { Time-loss } \\
\text { (>1 day) }\end{array}$ & $\begin{array}{l}61 \%(29 \% \text { tackled, } 32 \% \\
\text { tackling) }\end{array}$ & N/A \\
\hline Kerr et al ${ }^{7}$ & US collegiate teams (men) & $\begin{array}{l}\text { Overall and } \\
\text { time-loss } \\
\text { (>1 day) }\end{array}$ & $48 \%$ & $\begin{array}{l}8.2 / 1000 \text { hours } \\
(4.53 / 1000 \text { hours tackled, } \\
3.62 / 1000 \text { hours tackling) }\end{array}$ \\
\hline Kerr et al ${ }^{7}$ & US collegiate teams (women) & $\begin{array}{l}\text { Overall and } \\
\text { time-loss } \\
(>1 \text { day) }\end{array}$ & $53 \%$ & $\begin{array}{l}9.1 / 1000 \text { hours }(5.5 / 1000 \text { hours } \\
\text { tackled; } 3.6 / 1000 \text { hours } \\
\text { tackling) }\end{array}$ \\
\hline Haseler et al ${ }^{156}$ & $\begin{array}{l}\text { English youth community club } \\
\text { teams ( } 9-17 \text { years) }\end{array}$ & $\begin{array}{l}\text { Time-loss } \\
\text { (>1 day) }\end{array}$ & $59 \%$ & $\begin{array}{l}14 / 1000 \text { hours }(95 \% \mathrm{Cl} 8.0 \text { to } \\
19.8)\end{array}$ \\
\hline Nicol et $a^{33}$ & Scottish school teams & $\begin{array}{l}\text { Time-loss } \\
\text { (>1 day) }\end{array}$ & $\begin{array}{l}62 \%(40 \% \text { tackled, } 22 \% \\
\text { tackling) }\end{array}$ & N/A \\
\hline $\begin{array}{l}\text { Fuller and } \\
\text { Molloy }^{28}\end{array}$ & International under-20 teams & $\begin{array}{l}\text { Time-loss } \\
\text { (>1 day) }\end{array}$ & $\begin{array}{l}45 \%(26 \% \text { tackled, } 19 \% \\
\text { tackling) }\end{array}$ & N/A \\
\hline $\begin{array}{l}\text { Palmer-Green } \\
\text { et } a /^{32}\end{array}$ & $\begin{array}{l}\text { English Premiership youth } \\
\text { academy teams (16-18 years) }\end{array}$ & $\begin{array}{l}\text { Time-loss } \\
\text { (>1 day) }\end{array}$ & $\begin{array}{l}51 \%(30 \% \text { tackled, } 21 \% \\
\text { tackling) }\end{array}$ & $\begin{array}{l}21 / 1000 \text { hours }(12 / 1000 \text { hours } \\
\text { tackled [95\% } \mathrm{Cl} 8 \text { to } 17] ; \\
9 / 1000 \text { hours tackling }[95 \% \mathrm{Cl} \\
5 \text { to } 13])\end{array}$ \\
\hline Archbold et al ${ }^{157}$ & $\begin{array}{l}\text { Irish grammar school teams } \\
(16.8 \pm 0.8 \text { years) }\end{array}$ & $\begin{array}{l}\text { Time-loss } \\
\text { (>1 day) }\end{array}$ & $\begin{array}{l}48 \%(20 \% \text { tackled, } 28 \% \\
\text { tackling) }\end{array}$ & N/A \\
\hline Swain et $a l^{158}$ & Australian amateur club teams & $\begin{array}{l}\text { Overall and } \\
\text { time-loss } \\
\text { (>1 day) }\end{array}$ & $\begin{array}{l}69 \%(34 \% \text { tackled }[95 \% \mathrm{Cl} \\
25.6 \text { to } 42.1] ; 35 \% \text { tackling } \\
[95 \% \mathrm{Cl} 26.4 \text { to } 42.9])\end{array}$ & $\mathrm{N} / \mathrm{A}$ \\
\hline Burger et $a l^{95}$ & $\begin{array}{l}\text { South African under-18 } \\
\text { provincial Craven Week teams }\end{array}$ & $\begin{array}{l}\text { Overall and } \\
\text { time-loss } \\
\text { (>1 day) }\end{array}$ & $50 \%$ & $\begin{array}{l}27 / 1000 \text { hours }(95 \% \mathrm{Cl} 21 \text { to } \\
33)\end{array}$ \\
\hline Burger et $a l^{95}$ & $\begin{array}{l}\text { South African under-18 } \\
\text { provincial Craven Week teams }\end{array}$ & $\begin{array}{l}\text { Time-loss } \\
\text { (>1 day) }\end{array}$ & $\mathrm{N} / \mathrm{A}$ & $11 / 1000$ hours (95\% Cl 8 to 15$)$ \\
\hline Leung et $a l^{159}$ & $\begin{array}{l}\text { Australian Associated } \\
\text { Independent Colleges } \\
\text { interschool competition teams: } \\
\text { year } 5 \text { teams ( } 9-10 \text { year olds) to } \\
\text { open grades (17-18year olds) }\end{array}$ & $\begin{array}{l}\text { Overall and } \\
\text { time-loss } \\
\text { (>1 day) }\end{array}$ & $\begin{array}{l}55 \%(27 \% \text { tackled, } 28 \% \\
\text { tackling) }\end{array}$ & N/A \\
\hline
\end{tabular}


Table 2 Continued

\begin{tabular}{|c|c|c|c|c|}
\hline Study & Cohort & $\begin{array}{l}\text { Injury } \\
\text { definition }\end{array}$ & Injury frequency & Injury rate \\
\hline Leung et $a l^{132}$ & $\begin{array}{l}\text { Australian greater private school } \\
\text { competition teams: under- } 11 \\
\text { teams (10-11 year olds) to open } \\
\text { grades ( } 17-18 \text { year olds) }\end{array}$ & $\begin{array}{l}\text { Overall and } \\
\text { time-loss } \\
\text { ( }>1 \text { day) }\end{array}$ & $39 \%$ & N/A \\
\hline $\begin{array}{l}\text { Barden and } \\
\text { Stokes }^{52}\end{array}$ & $\begin{array}{l}\text { English elite under-18 } \\
\text { schoolboy teams: AASE league } \\
\text { matches }\end{array}$ & $\begin{array}{l}\text { Time-loss } \\
\text { (>1 day) }\end{array}$ & $\mathrm{N} / \mathrm{A}$ & $\begin{array}{l}42 / 1000 \text { hours }(95 \% \mathrm{Cl} \\
26 \text { to } 59)(20 / 1000 \text { hours } \\
\text { tackled [95\% Cl } 9 \text { to } 32] ; \\
22 / 1000 \text { hours tackling }[95 \% \mathrm{Cl} \\
10 \text { to } 34])\end{array}$ \\
\hline $\begin{array}{l}\text { Barden and } \\
\text { Stokes }^{52}\end{array}$ & $\begin{array}{l}\text { English elite under-18 } \\
\text { schoolboy teams: general (non- } \\
\text { AASE) matches }\end{array}$ & $\begin{array}{l}\text { Time-loss } \\
\text { (>1 day) }\end{array}$ & N/A & $\begin{array}{l}19 / 1000 \text { hours }(95 \% \mathrm{Cl} 12 \text { to } \\
25)(12 / 1000 \text { hours tackled } \\
\text { [95\% Cl } 7 \text { to } 17] ; 7 / 1000 \text { hours } \\
\text { tackling [95\% Cl } 3 \text { to } 11])\end{array}$ \\
\hline Sewry et al ${ }^{160}$ & $\begin{array}{l}\text { South African provincial } \\
\text { Youth Week teams: under-13, } \\
\text { under-16 and under-18 }\end{array}$ & $\begin{array}{l}\text { Time-loss } \\
\text { (>1 day) }\end{array}$ & N/A & $\begin{array}{l}11.4 / 1000 \text { hours }(4 / 1000 \text { hours } \\
\text { tackled [95\% } \mathrm{Cl} 3.2 \text { to } 4.9] \text {; } \\
7.4 / 1000 \text { hours tackling } \\
\text { [95\% Cl } 6.3 \text { to } 8.5] \text { ] }\end{array}$ \\
\hline Sewry et $\left.a\right|^{50}$ & $\begin{array}{l}\text { South African Western Cape } \\
\text { premier league under-16 school } \\
\text { teams }\end{array}$ & $\begin{array}{l}\text { Time-loss } \\
\text { (>1 day) }\end{array}$ & $\mathrm{N} / \mathrm{A}$ & $\begin{array}{l}18.3 / 1000 \text { hours } \\
(11.3 / 1000 \text { hours tackled } \\
\text { [95\% } \mathrm{Cl} 5.2 \text { to } 17.5] ; \\
7 / 100 \text { hours tackling }[95 \% \mathrm{Cl} \\
2.1 \text { to } 11.8])\end{array}$ \\
\hline
\end{tabular}

AASE, Achieving Academic and Sporting Excellence; N/A, not applicable.

and referee education. Using evidence from tackle injury mechanism and performance determinant studies, national injury prevention programmes such as New Zealand's Rugby Smart and South Africa's BokSmart programmes aim to educate rugby stakeholders on safe and effective tackle techniques. ${ }^{124} 134$ These educational tools are intended to modify player, coach and referee attitudes and behaviours, both in training and during matches. While these national injury prevention programmes have shown positive changes in player, coach and referee knowledge, ${ }^{124} 125$ this may not be enough to drive positive behaviour change. Indeed, Hendricks et al showed that even though a sample of youth coaches were aware of the high risk of injury during the tackle and the importance of proper tackle technique, this knowledge did not transfer into their actual tackle training sessions. ${ }^{131}$ Therefore, the next logical step is to apply the knowledge gained from tackle injury mechanism and performance determinant studies to improve tackle training.

The tackle is a highly technical and physical skill and, like any skill, should be developed though training. ${ }^{15} 135$ Despite this, research comparing training and matches suggests that tackle contact preparation during training is not adequate to meet the demands of tackle contact during matches. ${ }^{131} 136137$ Implementation research in sport argues that the ability to coach technique depends on how competent the coaches believe they are to do so $^{138}$; this is also true for coaching tackle technique. ${ }^{131} 136$ From a behaviour change perspective, to increase the likelihood of a desired behaviour requires a specific action plan ${ }^{139140}$ and the fostering of competencies, a concept known as 'boosting'. ${ }^{141}$ In line with these arguments, a group of rugby researchers and practitioners designed a tackle contact skill framework and training plan based on skill acquisition and skill development literature. ${ }^{142}$ The framework describes measurements that can be used to monitor and progress tackle training to ensure optimum transfer to matches. ${ }^{142}$ Although the efficacy and effectiveness of such a tackle training programme has yet to be studied, the framework and training plan serves as a starting point to design tackle training programmes and further develop tackle training concepts such as contact readiness (when introducing players to rugby), contact readiness as part of match warm-up, return to contact (for players returning from injury), contact capacity (maintaining proper technique while fatigued) and contact efficiency (highly proficient contact technique with minimal physical effort). Also, how other forms of physical preparation, for example, resistance training, influences tackle ability is yet to be investigated. Finally, most of what we know about tackle training is based on questionnaire studies; therefore, to better understand the implementation context, as well as 
Table 3 Tackle-related injury frequencies and rates in rugby sevens (all levels of play)

\begin{tabular}{|c|c|c|c|c|}
\hline Study & Cohort & Injury definition & Injury frequency & Injury rate \\
\hline Fuller et al ${ }^{161}$ & $\begin{array}{l}\text { International World Sevens Series } \\
\text { teams }\end{array}$ & $\begin{array}{l}\text { Time-loss } \\
\text { (>1 day) }\end{array}$ & $\begin{array}{l}52 \%(34 \% \text { tackled, } 18 \% \\
\text { tackling) }\end{array}$ & $\mathrm{N} / \mathrm{A}$ \\
\hline Lopez et $a l^{46}$ & $\begin{array}{l}\text { US amateur rugby union sevens } \\
\text { teams (including women) }\end{array}$ & $\begin{array}{l}\text { Overall and time- } \\
\text { loss ( }>1 \text { day) }\end{array}$ & $75 \%$ (95\% Cl 60 to 85$)$ & $\begin{array}{l}40.4 / 1000 \text { hours } \\
(95 \% \mathrm{Cl} 28.6 \text { to } \\
55.6)\end{array}$ \\
\hline Fuller et $a l^{44}$ & $\begin{array}{l}\text { International World Sevens Series } \\
\text { teams }\end{array}$ & $\begin{array}{l}\text { Time-loss } \\
(>1 \text { day })\end{array}$ & $\begin{array}{l}54 \%(32 \% \text { tackled }[95 \% \mathrm{Cl} \\
27.1 \text { to } 37.6] ; 22 \% \text { tackling } \\
[95 \% \mathrm{Cl} 17.1 \text { to } 26.3])\end{array}$ & N/A \\
\hline Fuller et $a l^{43}$ & $\begin{array}{l}\text { International World Sevens Series } \\
\text { teams }\end{array}$ & $\begin{array}{l}\text { Time-loss } \\
\text { (>1 day) }\end{array}$ & $\begin{array}{l}55 \% \text { (33\% tackled, } 22 \% \\
\text { tackling) }\end{array}$ & $\mathrm{N} / \mathrm{A}$ \\
\hline Ma et $a l^{47}$ & $\begin{array}{l}\text { US women's rugby union sevens } \\
\text { teams (under- } 19 \text { to professional) }\end{array}$ & $\begin{array}{l}\text { Time -loss } \\
\text { (>1 day) }\end{array}$ & $\begin{array}{l}72 \% \pm 8.5 \% \text { ( } 41 \% \text { tackled, } 31 \% \\
\text { tackling) }\end{array}$ & N/A \\
\hline Rizi et al ${ }^{162}$ & Hong Kong University rugby teams & $\begin{array}{l}\text { Time-loss } \\
\text { (>1 day) }\end{array}$ & $\begin{array}{l}65 \% \text { ( } 29 \% \text { tackled, } 29 \% \\
\text { tackling, } 7 \% \text { tackle collision, ie, } \\
\text { no use of arm) }\end{array}$ & $\mathrm{N} / \mathrm{A}$ \\
\hline $\begin{array}{l}\text { Cruz-Ferreira et } \\
\mathrm{al}^{163}\end{array}$ & $\begin{array}{l}\text { Tier } 1 \text { and tier } 2 \text { Portuguese } \\
\text { national senior male rugby teams }\end{array}$ & $\begin{array}{l}\text { Time-loss }(>1 \\
\text { day) }\end{array}$ & $\begin{array}{l}57.1 \% \text { (38.1\% tackled [95\% Cl } \\
17.6 \% \text { to } 60.0 \%] ; 19 \% \text { tackling } \\
[95 \% \mathrm{Cl} 4.8 \% \text { to } 38.1 \%])\end{array}$ & $\mathrm{N} / \mathrm{A}$ \\
\hline $\begin{array}{l}\text { Cruz-Ferreira et } \\
\mathrm{al}^{163}\end{array}$ & $\begin{array}{l}\text { Tier } 1 \text { Portuguese national senior } \\
\text { male rugby Sevens teams }\end{array}$ & $\begin{array}{l}\text { Time-loss } \\
(>1 \text { day })\end{array}$ & $\begin{array}{l}57.2 \%(42.9 \% \text { tackled }[95 \% \mathrm{Cl} \\
15.4 \% \text { to } 70.0 \%] ; 14.3 \% \\
\text { tackling }[95 \% \mathrm{Cl} 0 \% \text { to } 35.7 \%])\end{array}$ & $\mathrm{N} / \mathrm{A}$ \\
\hline $\begin{array}{l}\text { Cruz-Ferreira et } \\
\mathrm{al}^{163}\end{array}$ & $\begin{array}{l}\text { Tier } 2 \text { Portuguese national senior } \\
\text { male rugby Sevens teams }\end{array}$ & $\begin{array}{l}\text { Time-loss } \\
(>1 \text { day })\end{array}$ & $\begin{array}{l}57.2 \%(28.6 \% \text { tackled }[95 \% \mathrm{Cl} \\
0 \% \text { to } 66.7 \% \text { ]; } 28.6 \% \text { tackling } \\
[95 \% \mathrm{Cl} 0 \% \text { to } 66.7 \%])\end{array}$ & N/A \\
\hline
\end{tabular}

N/A, not applicable.

barrier and facilitators to implementing a tackle training programme, coach engagement and systematic observations of tackle training sessions are required.

Another strategy to modify player tackle action during matches is through changing the laws of the game. To specifically reduce head injuries during the tackle, the sport's governing body, World Rugby, have recently recommended stronger sanctioning of reckless and high tackles and proposed a reduction in tackle height of a legal tackle, ${ }^{61}$ from above the line of the shoulders to above the line of the armpit. These law changes are seemingly based on the behavioural principle known as 'nudging', that is, changing the external environment to achieve a predicable outcome. ${ }^{141}$ Changing tackle laws also has a more immediate effect compared with education and training programmes. With that said, the actual effect of these law changes on tackle injury risk and player tackle actions is yet to be published.

Although results from lab-based studies may have limited applicability to match situations due to its controlled nature, studying the tackle in the lab allows for experiential and explorative study designs. Experiential and explorative study designs may offer deeper insights into the demands and movement patterns of the tackle (eg, tackle biomechanics), ${ }^{103}$ as well as test the effects of different conditions (eg, physical fatigue) and interventions (video feedback) ${ }^{143}$ on tackle technique. Not all research on the tackle needs to have a direct application, and experiential and explorative work is important to inspire innovative tackle injury prevention and performance strategies. ${ }^{144}$ Having said that, findings from tackle injury and performance studies in matches, as well stakeholder engagement, should guide the questions and design of lab-based studies.

\section{CONCLUSION}

The purpose of this review was to synthesise both injury prevention and performance tackle-related research to offer rugby stakeholders (researchers, practitioners, policymakers and coaches) with tackle-specific injury epidemiology and frequencies, an overview of tackle injury risk factors and performance determinants, discuss measures to improve tackle performance and reduce the risk of tackle injuries. The tackle consistently accounted for more than $50 \%$ of all injuries in rugby union and rugby sevens, both at the professional level and at the lower levels, with the rate of tackle injuries higher at the professional level (mean 32/1000 player-hours) compared with the lower levels (mean 17/1000 playerhours). Also, the frequencies of injury between the ball carrier and tackler were not largely dissimilar. A player's tackle actions and technical ability has been identified as a major risk factor for injury and a key determinant of performance. Evidence-based education has been used, and progressive tackle technique training with a high potential to transfer and law changes have been 
Table 4 Tackle numbers and rates in rugby union (all levels of play)

\begin{tabular}{lll}
\hline Study & Cohort & Rate definition \\
\hline Duthie $t \mathrm{al}^{164}$ & Super 12 teams & Tackling/game \\
& & \\
Deutsch et $a l^{165}$ & Super 12 team & $\begin{array}{l}\text { Tackles (tackling and tackled)/ } \\
\text { game }\end{array}$
\end{tabular}

\section{Tackle rate}

Front-row forwards: $10 \pm 8$

Back-row forwards: $13 \pm 5$

Inside backs: $11 \pm 6$

Outside backs: $7 \pm 4$

Front-row forwards: $9.5 \pm 3$

Back-row forwards: $23 \pm 6$

Inside backs: $20 \pm 4.5$

Outside backs: $11 \pm 6.5$

\begin{tabular}{|c|c|c|}
\hline Eaton and George ${ }^{166}$ & English Premiership team & $\begin{array}{l}\text { a) Tackling/game } \\
\text { b) Tackled/game }\end{array}$ \\
\hline Fuller et $a l^{20}$ & English Premiership teams & $\begin{array}{l}\text { Total match tackles (tackling } \\
\text { and tackled) }\end{array}$ \\
\hline $\begin{array}{l}\text { Quarrie and } \\
\text { Hopkins }^{167}\end{array}$ & Bledisloe Cup teams & $\begin{array}{l}\text { Total match tackles (tackling } \\
\text { and tackled) }\end{array}$ \\
\hline Roberts et al ${ }^{168}$ & English Premiership team & Tackling/game \\
\hline Smart et $a^{99}$ & $\begin{array}{l}\text { New Zealand National Provincial } \\
\text { Championship team }\end{array}$ & $\begin{array}{l}\text { a) Tackling/game } \\
\text { b) Tackled/game }\end{array}$ \\
\hline Austin et al ${ }^{169}$ & Super 14 team & $\begin{array}{l}\text { Tackles (tackling and tackled)/ } \\
\text { game }\end{array}$ \\
\hline
\end{tabular}

Props: $8 \pm 4,{ }^{a} 5 \pm 3^{b}$

Hooker: $8 \pm 4,{ }^{a} 7 \pm 4^{b}$

Lock forwards: $11 \pm 3,{ }^{a} 4 \pm 2^{b}$

Loose forwards: $13 \pm 6,{ }^{a} 8 \pm 5^{b}$

Scrum halves: $11 \pm 4,{ }^{a} 9 \pm 4^{b}$

Inside backs: $9 \pm 4,{ }^{a} 5 \pm 3^{b}$

Outside backs: $6 \pm 3,{ }^{a} 5 \pm 3^{b}$

221 (95\% Cl 215.9 to 226.2)

1995: $160 \pm 32$

2004: $270 \pm 25$

Tight forwards: $12 \pm 3$

Loose forwards $16 \pm 4$

Inside backs: $13 \pm 3$

Outside backs: $8 \pm 2$

Forwards: $13.6 \pm 7.5,{ }^{\mathrm{a}} 3.2 \pm 2.4^{\mathrm{b}}$

Backs: $6.5 \pm 4.7,{ }^{\mathrm{a}} 0.7 \pm 0.9^{\mathrm{b}}$

Front-row forwards: $20 \pm 4$

Back-row forwards: $19 \pm 4$

Inside backs: $25 \pm 13$

Outside backs: $20 \pm 7$

Back: $12,{ }^{a} 4^{b}$

\begin{tabular}{lll}
\hline $\begin{array}{ll}\text { Coughlan et al } \\
\text { 100 }\end{array}$ & $\begin{array}{l}\text { International players (one forward } \\
\text { and back) }\end{array}$ & $\begin{array}{l}\text { a) Tackling/game } \\
\text { b) Tackled/game }\end{array}$ \\
van Rooyen $^{170}$ & International teams & $\begin{array}{l}\text { Total match tackles (tackling } \\
\text { and tackled) }\end{array}$
\end{tabular}

$\begin{array}{lll}\text { Hendricks et al }{ }^{171} \quad \text { Super } 14 \text { teams } & \begin{array}{l}\text { Total match tackles (tackling } \\ \text { and tackled) }\end{array}\end{array}$

Tackling/game

Forward: $10,{ }^{a} 5^{b}$

Six Nations: $165 \pm 28$

Tri Nations: $141 \pm 24$

2011 Rugby World Cup:156×47

Front-row forwards: 10.04

Lock forwards: 10.94

Back-row forwards: 14.25

Scrum halves: 12.48

Inside backs: 10.46

Outside backs: 5.9

\begin{tabular}{|c|c|c|c|}
\hline Hendricks et $a l^{98}$ & Super 14 teams & $\begin{array}{l}\text { Total match tackles (tackling } \\
\text { and tackled) }\end{array}$ & $116 \pm 20$ \\
\hline \multirow[t]{2}{*}{ Jones et $a l^{101}$} & European Cup team & a) Tackling/game & Forwards: $5 \pm 3,{ }^{a} 5 \pm 2^{b}$ \\
\hline & & b) Tackled/game & Backs: $4 \pm 3,{ }^{a} 5 \pm 3^{b}$ \\
\hline
\end{tabular}

Continued 
Table 4 Continued

\begin{tabular}{llll}
\hline Study & Cohort & Rate definition & Tackle rate \\
\hline van Rooyen et ll $^{173}$ & Six Nations team & $\begin{array}{l}\text { Total match tackles (tackling } \\
\text { and tackled) }\end{array}$ & $191 \pm 32$
\end{tabular}

Lindsay et ll $^{174} \quad$ Super 15 team $\quad$ c) Tackling/minute

d) Tackled/minute

\begin{tabular}{|c|c|c|c|}
\hline Roberts et $a l^{6}$ & $\begin{array}{l}\text { Amateur English community-level } \\
\text { teams }\end{array}$ & $\begin{array}{l}\text { Total match tackles (tackling } \\
\text { and tackled) }\end{array}$ & $140.9(95 \% \mathrm{Cl} 136.7$ to 145.2$)$ \\
\hline Villarejo et al $^{175}$ & 2011 RWC teams & Tackling/game & $\begin{array}{l}\text { Front-row forwards: } 9.96 \\
\text { Lock forwards: } 10.9 \\
\text { Back-row forwards: } 14.36 \\
\text { Scrum halves: } 12.44 \\
\text { Inside backs: } 10.35 \\
\text { Outside backs: } 5.95\end{array}$ \\
\hline Brown et $a^{176}$ & $\begin{array}{l}\text { South African under-18 provincial } \\
\text { Craven Week teams }\end{array}$ & $\begin{array}{l}\text { Total match tackles (tackling } \\
\text { and tackled) }\end{array}$ & $123 \pm 17$ \\
\hline Hendricks et $a^{97}$ & Six Nations teams & $\begin{array}{l}\text { Total match tackles (tackling } \\
\text { and tackled) }\end{array}$ & $175 \pm 21$ \\
\hline
\end{tabular}

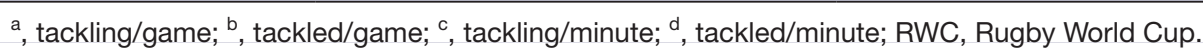

proposed, as key modifiers of player tackle actions and technical ability. Conceivably, all three modifiers working in unison (as oppose to separately) will have a higher potential at reducing tackle injury risk while enhancing performance. With the guidance of tackle injury and performance studies, as well as stakeholder engagement, experiential and explorative tackle research also has potential to inspire innovative tackle injury prevention and performance strategies.

Twitter Nicholas Burger @it_is_burger, Mike Lambert @MikeLambert 01 and Sharief Hendricks @Sharief_H

Contributors NB conducted the search and review, NB and SH cowrote the first draft, and all authors provided input to the final version.

Table 5 Tackle numbers and rates in rugby sevens (all levels of play).

\begin{tabular}{|c|c|c|c|}
\hline Study & Cohort & Rate definition & Tackle rate \\
\hline \multirow[t]{2}{*}{ Suarez-Arrones et al ${ }^{177}$} & \multirow[t]{2}{*}{$\begin{array}{l}\text { Professional Spanish League } \\
\text { team }\end{array}$} & \multirow[t]{2}{*}{$\begin{array}{l}\text { Tackles (tackling and } \\
\text { tackled)/game }\end{array}$} & $\begin{array}{l}\text { Forwards: } 7.4 \pm 1.8 \text { (first half: } 3.3 \pm 1.3 \\
\text { second half: } 4.1 \pm 1.8 \text { ) }\end{array}$ \\
\hline & & & $\begin{array}{l}\text { Backs: } 4.1 \pm 2.4 \text { (first half: } 2.3 \pm 1.8 \text {, second } \\
\text { half: } 1.9 \pm 1.4 \text { ) }\end{array}$ \\
\hline Ross et al ${ }^{178}$ & $\begin{array}{l}\text { New Zealand provincial rugby } \\
\text { sevens championship teams }\end{array}$ & Tackling/minute & $0.19 \pm 0.13$ \\
\hline Ross et al ${ }^{178}$ & $\begin{array}{l}\text { International Sevens World } \\
\text { Series team }\end{array}$ & Tackling/minute & $0.2 \pm 0.15$ \\
\hline \multirow[t]{2}{*}{ Ross et al ${ }^{179}$} & \multirow{2}{*}{$\begin{array}{l}\text { International Sevens World } \\
\text { Series team }\end{array}$} & a) Tackling/game & Forwards: $2.68 \pm 2.59,{ }^{\mathrm{a}} 1.59 \pm 2.24^{\mathrm{b}}$ \\
\hline & & b) Tackled/game & Backs: $2.41 \pm 2.52,^{\mathrm{a}} 1.79 \pm 2.85^{\mathrm{b}}$ \\
\hline
\end{tabular}

a , tackling/game; ${ }^{\mathrm{b}}$, tackled/game. 


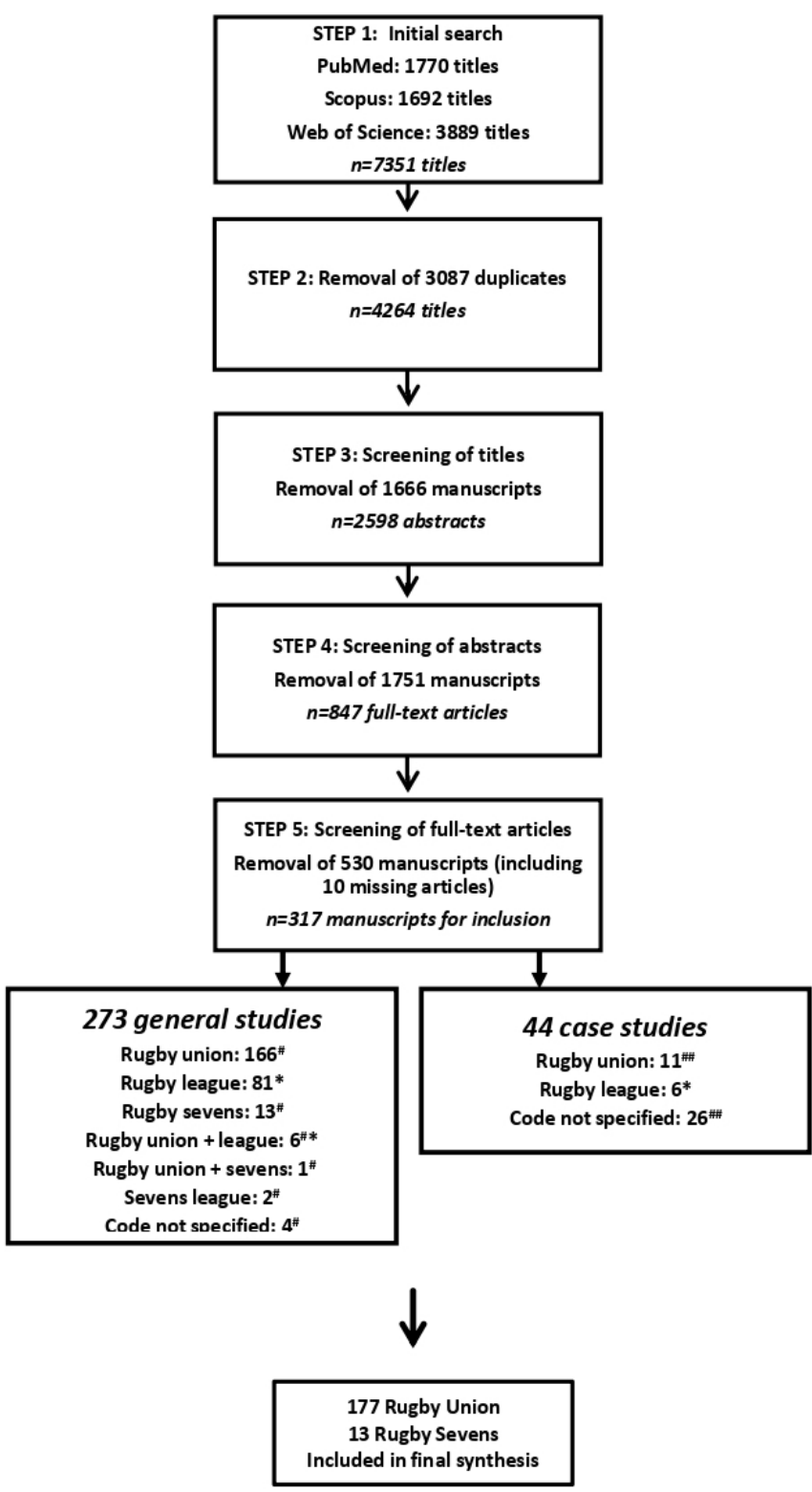

Figure 1 Summary of the literature screening process. \#, manuscripts included in rugby union/sevens analysis; \#\#, manuscripts included in rugby union/sevens appendix; *, manuscripts included in separate rugby league analysis/ appendix.

Funding This work was supported by the UCT Faculty of Health Sciences Postgraduate Publication Incentive Award and the National Research Foundation (NRF).

Competing interests None declared.

Patient consent for publication Not required.

Provenance and peer review Not commissioned; externally peer reviewed.

Data availability statement All data relevant to the study are included in the article or uploaded as supplementary information.

Open access This is an open access article distributed in accordance with the Creative Commons Attribution Non Commercial (CC BY-NC 4.0) license, which permits others to distribute, remix, adapt, build upon this work non-commercially, and license their derivative works on different terms, provided the original work is properly cited, appropriate credit is given, any changes made indicated, and the use is non-commercial. See: http://creativecommons.org/licenses/by-nc/4.0/.
Nicholas Burger http://orcid.org/0000-0002-0010-9212

Mike Lambert http://orcid.org/0000-0001-8979-1504

Sharief Hendricks http://orcid.org/0000-0002-3416-6266

\section{REFERENCES}

1 Williams S, Trewartha G, Kemp S, et al. A meta-analysis of injuries in senior men's professional rugby union. Sports Med 2013;43:1043-55.

2 Yeomans C, Kenny IC, Cahalan R, et al. The incidence of injury in amateur male rugby union: a systematic review and meta-analysis. Sports Med 2018;48:837-48

3 Freitag A, Kirkwood G, Scharer S, et al. Systematic review of rugby injuries in children and adolescents under 21 years. $\mathrm{Br} J$ Sports Med 2015;49:511-9.

4 Cruz-Ferreira A, Cruz-Ferreira E, Santiago L, et al. Epidemiology of injuries in senior male rugby union sevens: a systematic review. Phys Sportsmed 2017;45:41-8.

5 Chan CW, Eng JJ, Tator $\mathrm{CH}$, et al. Epidemiology of sport-related spinal cord injuries: a systematic review. J Spinal Cord Med 2016;39:255-64.

6 Roberts SP, Trewartha G, England M, et al. Collapsed scrums and collision tackles: what is the injury risk? Br J Sports Med 2015;49:536-40.

7 Kerr HA, Curtis C, Micheli LJ, et al. Collegiate rugby union injury patterns in New England: a prospective cohort study. $\mathrm{Br} J$ Sports Med 2008;42:595-603.

8 Schwellnus MP, Thomson A, Derman W, et al. More than $50 \%$ of players sustained a time-loss injury ( $>1$ day of lost training or playing time) during the 2012 Super Rugby Union Tournament: a prospective cohort study of 17,340 player-hours. Br J Sports Med 2014;48:1306-15.

9 Burger N, Lambert MI, Viljoen W, et al. Tackle-related injury rates and nature of injuries in South African youth week tournament rugby union players (under-13 to under-18): an observational cohort study. BMJ Open 2014;4:e005556.

10 Quarrie KL, Hopkins WG. Tackle injuries in professional rugby union. Am J Sports Med 2008;36:1705-16.

11 Fuller CW, Ashton T, Brooks JHM, et al. Injury risks associated with tackling in rugby union. Br J Sports Med 2010;44:159-67.

12 Ortega E, Villarejo D, Palao JM. Differences in game statistics between winning and losing rugby teams in the six nations tournament. J Sports Sci Med 2009;8:523-7.

13 Finch C. A new framework for research leading to sports injury prevention. J Sci Med Sport 2006;9:3-9.

14 Bishop D. An applied research model for the sport sciences. Sports Med 2008;38:253-63.

15 Hendricks S, Till K, Brown JC, et al. Rugby Union needs a contact skill-training programme. Br J Sports Med 2017;51:829-30.

16 Popay J, Roberts H, Sowden A. Guidance on the conduct of narrative synthesis in systematic reviews: a product from the ESRC methods programme, 2006.

17 Druetz T, Siekmans K, Goossens S, et al. The community case management of pneumonia in Africa: a review of the evidence. Health Policy Plan 2015;30:253-66.

18 Garraway WM, Lee AJ, Macleod DA, et al. Factors influencing tackle injuries in rugby union football. Br J Sports Med 1999;33:37-41.

19 McIntosh AS, Savage TN, McCrory P, et al. Tackle characteristics and injury in a cross section of rugby union football. Med Sci Sports Exerc 2010;42:977-84.

20 Fuller CW, Brooks JHM, Cancea RJ, et al. Contact events in rugby union and their propensity to cause injury. Br J Sports Med 2007;41:862-7.

21 Brooks JHM, Fuller CW, Kemp SPT, et al. Epidemiology of injuries in English professional rugby union: Part 1 match injuries. $\mathrm{Br} \mathrm{J}$ Sports Med 2005;39:757-66.

22 Brooks JHM, Kemp SPT. Injury-prevention priorities according to playing position in professional rugby union players. $\mathrm{Br} J$ Sports Med 2011:45:765-75.

23 Best JP, Mcintosh AS, Savage TN, et al. Injury surveillance project. Br J Sports Med 2003;2005:812-7.

24 Fuller CW, Laborde F, Leather RJ, et al. International rugby board rugby world cup 2007 injury surveillance study. Br J Sports Med 2008:42:452-9.

25 Fuller CW, Sheerin K, Targett S, et al. International rugby board injury surveillance study. Br J Sports Med 2011;2013:1184-91.

26 Fuller CW, Taylor A, Kemp SPT, et al. World rugby injury surveillance study. Br J Sports Med 2015;2016:1-7. 
27 Taylor AE, Fuller CW, Molloy MG. Injury surveillance during the 2010 IRB women's rugby world cup. Br J Sports Med 2011;45:1243-5.

28 Fuller CW, Molloy MG, Marsalli M. Epidemiological study of injuries in men's international under-20 rugby union tournaments. Clin $J$ Sport Med 2011;21:356-8.

29 Garraway WM, Lee AJ, Hutton SJ, et al. Impact of professionalism on injuries in rugby union. Br J Sports Med 2000;34:348-51.

30 Roberts SP, Trewartha G, England M, et al. Epidemiology of timeloss injuries in English community-level rugby union. BMJ Open 2013;3:e003998:1-8.

31 Collins CL, Micheli LJ, Yard EE, et al. Injuries sustained by high school rugby players in the United States, 2005-2006. Arch Pediatr Adolesc Med 2008;162:49-54.

32 Palmer-Green DS, Stokes KA, Fuller CW, et al. Match injuries in English youth Academy and schools rugby union: an epidemiological study. Am J Sports Med 2013;41:749-55.

33 Nicol A, Pollock A, Kirkwood G, et al. Rugby Union injuries in Scottish schools. J Public Health 2011;33:256-61.

34 Usman J, McIntosh AS, Usman MAS. Upper limb injury in rugby union football: results of a cohort study. Br J Sports Med 2013;47:374-9.

35 Babić Z, Misigoj-Duraković M, Matasić H, et al. Croatian rugby project. Part II: injuries. J Sports Med Phys Fitness 2001;41:392-8.

36 Brooks JHM, Fuller CW, Kemp SPT, et al. Epidemiology of injuries in English professional rugby union: Part 2 training injuries. $\mathrm{Br} \mathrm{J}$ Sports Med 2005;39:767-75.

37 Palmer-Green DS, Stokes KA, Fuller CW, et al. Training activities and injuries in English youth Academy and schools rugby union. Am J Sports Med 2015;43:475-81.

38 Goodson A, Morgan M, Rajeswaran G, et al. Current management of Jersey finger in rugby players: case series and literature review. Hand Surg 2010;15:103-7.

39 Muller-Bolla M, Lupi-Pegurier L, Pedeutour P, et al. Orofacial trauma and rugby in France: epidemiological survey. Dent Traumatol 2003;19:183-92.

40 Kemp SPT, Hudson Z, Brooks JHM, et al. The epidemiology of head injuries in English professional rugby union. Clin J Sport Med 2008;18:227-34.

41 Mclntosh AS, McCrory P, Finch CF, et al. Head, face and neck injury in youth rugby: incidence and risk factors. Br J Sports Med 2010;44:188-93.

42 Robertson GAJ, Wood AM, Heil K, et al. The epidemiology, morbidity and outcome of fractures in rugby union from a standard population. Injury 2014;45:677-83.

43 Fuller CW, Taylor AE, Raftery M. Should player fatigue be the focus of injury prevention strategies for international rugby sevens tournaments? Br J Sports Med 2016;50:682-7.

44 Fuller CW, Taylor AE, Raftery M. Does long-distance air travel associated with the Sevens world series increase players' risk of injury? Br J Sports Med 2015;49:458-64.

45 King DA, Gabbett TJ, Dreyer C, et al. Incidence of injuries in the New Zealand national rugby League sevens tournament. J Sci Med Sport 2006;9:110-8.

46 Lopez V, Galano GJ, Black CM, et al. Profile of an American amateur rugby union sevens series. Am J Sports Med 2012;40:179-84.

47 Ma R, Lopez V, Weinstein MG, et al. Injury profile of American women's Rugby-7s. Med Sci Sports Exerc 2016;48:1957-66.

48 Burger N, Lambert MI, Viljoen W, et al. Mechanisms and factors associated with tackle-related injuries in South African youth rugby union players. Am J Sports Med 2017;45:278-85.

49 Snodgrass SJ, Osmotherly PG, Reid SA, et al. Physical characteristics associated with neck pain and injury in rugby union players. J Sports Med Phys Fitness 2018;58:1474-81.

50 Sewry N, Verhagen E, Lambert M, et al. Seasonal time-loss match injury rates and burden in South African under-16 rugby teams. $J$ Sci Med Sport 2019;22:54-8.

51 Ranson C, George J, Rafferty J, et al. Playing surface and UK professional rugby union injury risk. J Sports Sci 2018;36:2393-8.

52 Barden C, Stokes K. Epidemiology of injury in elite English Schoolboy rugby union: a 3-year study comparing different competitions. J Athl Train 2018;53:514-20.

53 Cross M, Kemp S, Smith A, et al. Professional Rugby Union players have a $60 \%$ greater risk of time loss injury after concussion: a 2 -season prospective study of clinical outcomes. Br J Sports Med 2015;0:1-6.

54 Fuller CW, Taylor A, Raftery M. Epidemiology of concussion in men's elite Rugby-7s (Sevens world series) and Rugby-15s (rugby world cup, junior world Championship and rugby Trophy,
Pacific nations cup and English Premiership). Br J Sports Med 2015;49:478-83.

55 Fuller GW, Kemp SPT, Decq P. The International rugby board (IRB) pitch side concussion assessment trial: a pilot test accuracy study. Br J Sports Med 2015;49:529-35.

56 Tierney GJ, Lawler J, Denvir K, et al. Risks associated with significant head impact events in elite rugby union. Brain Inj 2016;30:1350-61

57 Delahunty SE, Delahunt E, Condon B, et al. Prevalence of and attitudes about concussion in Irish schools' rugby union players. $J$ Sch Health 2015;85:17-26.

58 Lopez V, Ma R, Weinstein MG, et al. Concussive injuries in rugby 7S: an American experience and current review. Med Sci Sports Exerc 2016;48:1320-30.

59 Cross MJ, Tucker R, Raftery M, et al. Tackling concussion in professional rugby union: a case-control study of tackle-based risk factors and recommendations for primary prevention. $\mathrm{Br} J$ Sports Med 2017:1-6.

60 Tucker R, Raftery M, Fuller GW, et al. A video analysis of head injuries satisfying the criteria for a head injury assessment in professional rugby union: a prospective cohort study. $\mathrm{Br} J$ Sports Med 2017:51:1147-51.

61 Tucker R, Raftery M, Kemp S, et al. Risk factors for head injury events in professional rugby union: a video analysis of 464 head injury events to inform proposed injury prevention strategies. $\mathrm{Br} \mathrm{J}$ Sports Med 2017;51:1152-7.

62 Roberts SP, Trewartha G, England M, et al. Concussions and head injuries in English community rugby union match play. Am J Sports Med 2017;45:480-7.

63 Mc Fie S, Brown J, Hendricks S, et al. Incidence and factors associated with concussion injuries at the 2011 to 2014 South African rugby union youth week Tournaments. Clin J Sport Med 2016;26:398-404.

64 Tierney GJ, Denvir K, Farrell G, et al. Does ball carrier technique influence tackler head injury assessment risk in elite rugby union? J Sports Sci 2019;37:262-7.

65 Davidow D, Quarrie K, Viljoen W, et al. Tackle technique of rugby union players during head impact tackles compared to injury free tackles. J Sci Med Sport 2018;21:1025-31.

66 Tierney GJ, Simms CK. Can tackle height influence head injury assessment risk in elite rugby union? J Sci Med Sport 2018.

67 Fuller GW, Cross MJ, Stokes KA, et al. King-Devick concussion test performs poorly as a screening tool in elite rugby union players: a prospective cohort study of two screening tests versus a clinical reference standard. Br J Sports Med 2019;53:1526-32.

68 Clacy A, Goode N, Sharman R, et al. A knock to the system: a new sociotechnical systems approach to sport-related concussion. J Sports Sci 2017;35:2232-9.

69 Tierney GJ, Denvir K, Farrell G, et al. The effect of tackler technique on head injury assessment risk in elite rugby union. Med Sci Sports Exerc 2018;50:603-8.

70 Hendricks S, O'Connor S, Lambert M, et al. Video analysis of concussion injury mechanism in under-18 rugby. BMJ Open Sport Exerc Med 2016;2:e000053:1-11.

71 Fuller CW, Brooks JHM, Kemp SPT. Spinal injuries in professional rugby union: a prospective cohort study. Clin J Sport Med 2007;17:10-16.

72 Quarrie KL, Gianotti SM, Hopkins WG, et al. Effect of nationwide injury prevention programme on serious spinal injuries in New Zealand rugby union: ecological study. BMJ 2007;334:1150-3.

73 Carmody DJ, Taylor TKF, Parker DA, et al. Spinal cord injuries in Australian footballers 1997-2002. Med J Aust 2005;182:561-4.

74 Shelly MJ, Butler JS, Timlin M, et al. Spinal injuries in Irish rugby. $J$ Bone Joint Surg Br 2006;88-B:771-5.

75 Dunn RN, van der Spuy DRugby and cervical spine injuries - has anything changed? A 5-year review in the Western Cape. S Afr Med J 2010;100:235-8.

76 Brown JC, Lambert MI, Verhagen E, et al. The incidence of rugby-related catastrophic injuries (including cardiac events) in South Africa from 2008 to 2011: a cohort study. BMJ Open 2013;3:e002475:1-10.

77 Maclean JGB, Hutchison JD. Serious neck injuries in U19 rugby union players: an audit of admissions to spinal injury units in Great britain and ireland. Br J Sports Med 2011:1-5.

78 Swain MS, Pollard HP, Bonello R. Incidence, severity, aetiology and type of neck injury in men's amateur rugby union: a prospective cohort study. Chiropr Osteopat 2010;18:1-12.

79 Badenhorst M, Verhagen E, Lambert MI, et al. 'In a blink of an eye your life can change': experiences of players sustaining a rugbyrelated acute spinal cord injury. Inj Prev 2019;25:313-320. 
80 Headey J, Brooks JHM, Kemp SPT. The epidemiology of shoulder injuries in English professional rugby union. Am J Sports Med 2007;35:1537-43.

81 Usman J, Mclntosh AS, Quarrie K, et al. Shoulder injuries in elite rugby union football matches: epidemiology and mechanisms. $J$ Sci Med Sport 2015;18:529-33.

82 Kawasaki T, Ota C, Urayama S, et al. Incidence of and risk factors for traumatic anterior shoulder dislocation: an epidemiologic study in high-school rugby players. J Shoulder Elbow Surg 2014;23:1624-30.

83 Bohu Y, Klouche S, Lefevre N, et al. The epidemiology of 1345 shoulder dislocations and subluxations in French rugby union players: a five-season prospective study from 2008 to 2013. $\mathrm{Br} \mathrm{J}$ Sports Med 2015;49:1535-40.

84 Sundaram A, Bokor DJ, Davidson AS. Rugby Union on-field position and its relationship to shoulder injury leading to anterior reconstruction for instability. J Sci Med Sport 2011;14:111-4.

85 Lynch E, Lombard AJ, Coopoo Y, et al. Shoulder injury incidence and severity through identification of risk factors in rugby union players. Pak J Med Sci 2013;29:1400-5.

86 Singh VR, Trewartha G, Roberts SP, et al. Shoulder injuries in English community rugby union. Int J Sports Med 2016;37:659-64.

87 Larrain MV, Montenegro HJ, Mauas DM, et al. Arthroscopic management of traumatic anterior shoulder instability in collision athletes: analysis of 204 cases with a 4- to 9-year follow-up and results with the suture anchor technique. Arthroscopy 2006;22:1283-9.

88 Longo UG, Huijsmans PE, Maffulli N, et al. Video analysis of the mechanisms of shoulder dislocation in four elite rugby players. $J$ Orthop Sci 2011;16:389-97.

89 Sankey RA, Brooks JHM, Kemp SPT, et al. The epidemiology of ankle injuries in professional rugby union players. Am J Sports Med 2008;36:2415-24.

90 Dallalana RJ, Brooks JHM, Kemp SPT, et al. The epidemiology of knee injuries in English professional rugby union. Am J Sports Med 2007;35:818-30.

91 Takazawa $\mathrm{Y}$, Nagayama M, Ikeda $\mathrm{H}$, et al. Anterior cruciate ligament injuries in elite and high school rugby players: a 11-year review. Phys Sportsmed 2016;44:53-8.

92 Viljoen W, Treu P, Swart B. SA Rugby BokSmart: Safe and Effective Techniques in Rugby -Practical Guidelines.. Available: http://www. sarugby.co.za/boksmart/pdf/BokSmart\%25\%0A20-\%2520Safe\% 2520 Rugby\%2520Techniques\%2520Practical\%2520guidelines. pdf.2009 [Accessed 23 May 2012].

93 Montgomery C, Blackburn J, Withers D, et al. Mechanisms of ACL injury in professional rugby union: a systematic video analysis of 36 cases. Br J Sports Med 2018;52:994-1001.

94 Hendricks S, O'connor S, Lambert M, et al. Contact technique and concussions in the South African under-18 Coca-Cola Craven week rugby tournament. Eur J Sport Sci 2015;15:557-64.

95 Burger N, Lambert MI, Viljoen W, et al. Tackle technique and tackle-related injuries in high-level South African rugby union under-18 players: real-match video analysis. $\mathrm{Br} J$ Sports Med 2016;50:932-8

96 Sobue S, Kawasaki T, Hasegawa Y, et al. Tackler's head position relative to the ball carrier is highly correlated with head and neck injuries in rugby. Br J Sports Med 2018;52:353-8.

97 Hendricks S, van Niekerk T, Sin DW, et al. Technical determinants of tackle and ruck performance in international rugby union. $J$ Sports Sci 2018;36:522-8.

98 Hendricks S, Matthews B, Roode B, et al. Tackler characteristics associated with tackle performance in rugby union. Eur J Sport Sci 2014;14:753-62

99 Smart DJ, Gill ND, Beaven CM, et al. The relationship between changes in interstitial creatine kinase and game-related impacts in rugby union. Br J Sports Med 2008;42:198-201.

100 Coughlan GF, Green BS, Pook PT, et al. Physical game demands in elite rugby union: a global positioning system analysis and possible implications for rehabilitation. J Orthop Sports Phys Ther 2011;41:600-5.

101 Jones MR, West DJ, Harrington BJ, et al. Match play performance characteristics that predict post-match creatine kinase responses in professional rugby union players. BMC Sports Sci Med Rehabil 2014;6:38.

102 Herrington L, Horsley I. Electromyographic analysis of selected shoulder muscles during a rugby football tackle. BMC Sports Sci Med Rehabil 2009;1:1-7.

103 Seminati E, Cazzola D, Preatoni E, et al. Specific tackling situations affect the biomechanical demands experienced by rugby union players. Sports Biomech 2017;16:58-75.
104 Horsley IG, Herrington LC, Rolf C. Does a slap lesion affect shoulder muscle recruitment as measured by EMG activity during a rugby tackle? J Orthop Surg Res 2010;5:1-10.

105 Morimoto K, Sakamoto M, Fukuhara T, et al. Electromyographic study of neck muscle activity according to head position in rugby tackles. J Phys Ther Sci 2013;25:563-6.

106 Takarada Y. Evaluation of muscle damage after a rugby match with special reference to tackle plays. Br J Sports Med 2003;37:416-9.

107 Cunniffe B, Hore AJ, Whitcombe DM, et al. Time course of changes in immuneoendocrine markers following an international rugby game. Eur J Appl Physiol 2010;108:113-22.

108 Pointon M, Duffield R. Cold water immersion recovery after simulated collision sport exercise. Med Sci Sports Exerc 2012;44:206-16.

109 Takeda M, Sato T, Hasegawa T, et al. The effects of cold water immersion after rugby training on muscle power and biochemical markers. J Sports Sci Med 2014;13:616-23.

110 Hinckson EA, Hamlin MJ, Wood MR, et al. Game performance and intermittent hypoxic training. Br J Sports Med 2007;41:537-9.

111 Hamlin MJ, Hinckson EA, Wood MR, et al. Simulated rugby performance at 1550-m altitude following adaptation to intermittent normobaric hypoxia. J Sci Med Sport 2008;11:593-9.

112 Stuart GR, Hopkins WG, Cook C, et al. Multiple effects of caffeine on simulated high-intensity team-sport performance. Med Sci Sports Exerc 2005;37:1998-2005.

113 Roe G, Darrall-Jones J, Till K, et al. The effect of physical contact on changes in fatigue markers following rugby union field-based training. Eur J Sport Sci 2017;17:647-55.

114 Wundersitz DW, Gastin PB, Robertson SJ, et al. Validity of a trunkmounted accelerometer to measure physical collisions in contact sports. Int J Sports Physiol Perform 2015;10:681-6.

115 Hendricks S, Karpul D, Nicolls F, et al. Velocity and acceleration before contact in the tackle during rugby union matches. J Sports Sci 2012;30:1215-24.

116 Hendricks S, Karpul D, Lambert M. Momentum and kinetic energy before the tackle in rugby union. J Sports Sci Med 2014;13:557-63.

117 Usman J, Mclntosh AS, Fréchède B. An investigation of shoulder forces in active shoulder tackles in rugby union football. J Sci Med Sport 2011;14:547-52

118 Pain MTG, Tsui F, Cove S. In vivo determination of the effect of shoulder pads on tackling forces in rugby. J Sports Sci 2008;26:855-62.

119 Tierney GJ, Simms CK. The effects of tackle height on inertial loading of the head and neck in rugby union: a multibody mode analysis. Brain Inj 2017;31:1925-31.

120 Ashworth B, Hogben P, Singh N, et al. The athletic shoulder (ash) test: reliability of a novel upper body isometric strength test in elite rugby players. BMJ Open Sport Exerc Med 2018;4:e000365

121 Kawasaki T, Tanabe Y, Tanaka $\mathrm{H}$, et al. Kinematics of rugby tackling: a pilot study with 3-dimensional motion analysis. Am J Sports Med 2018;46:2514-20.

122 MacLeod SJ, Hagan C, Egaña M, et al. The use of microtechnology to monitor collision performance in professional rugby union. Int $J$ Sports Physiol Perform 2018;13:1075-82.

123 Tierney GJ, Richter C, Denvir K, et al. Could lowering the tackle height in rugby union reduce ball carrier inertial head kinematics? $J$ Biomech 2018;72:29-36.

124 Gianotti SM, Quarrie KL, Hume PA. Evaluation of RugbySmart: a rugby union community injury prevention programme. J Sci Med Sport 2009;12:371-5.

125 Brown JC, Gardner-Lubbe S, Lambert MI, et al. The BokSmart intervention programme is associated with improvements in injury prevention behaviours of rugby union players: an ecological crosssectional study. Inj Prev 2015;21:173-8.

126 Hendricks S, Jordaan E, Lambert M. Attitude and behaviour of junior rugby union players towards tackling during training and match play. Saf Sci 2012;50:266-84.

127 Hendricks S, den Hollander S, Tam N, et al. The relationships between rugby players' tackle training attitudes and behaviour and their match tackle attitudes and behaviour. BMJ Open Sport Exerc Med 2015:1-8.

128 Cooney M, Coleman F, Flynn A. A study of the knowledge that school rugby coaches have in the management and prevention of serious neck injury. Ir Med J 2000;93:171-4.

129 Carter AF, Muller R. A survey of injury knowledge and technical needs of junior rugby union coaches in Townsville (North Queensland). J Sci Med Sport 2008;11:167-73.

130 Brown JC, Gardner-Lubbe S, Lambert MI, et al. Coach-directed education is associated with injury-prevention behaviour in players: an ecological cross-sectional study. $\mathrm{Br} J$ Sports Med 2018:52:989-93. 
131 Hendricks S, Sarembock M, Jones B, et al. The tackle in South African youth rugby union - gap between coaches' knowledge and training behaviour. Int J Sports Sci Coach 2017;12:708-15.

132 Leung FT, Franettovich Smith MM, Hides JA. Injuries in Australian school-level rugby union. J Sports Sci 2017;35:2088-92.

133 Morgan R, Herrington L. The effect of tackling on shoulder joint positioning sense in semi-professional rugby players. Phys Ther Sport 2014;15:176-80.

134 Viljoen W, Patricios J. BokSmart - implementing a National Rugby Safety Programme. Br J Sports Med 2012;46:692-3.

135 Hendricks S, Lambert MI. Theoretical model describing the relationship between the number of tackles in which a player engages, tackle injury risk and tackle performance. J Sports Sci Med 2014;13:715-7.

136 Hendricks S, Sarembock M. Attitudes and behaviours of top-level junior rugby union coaches towards the coaching of proper contact technique in the tackle - a pilot study. S Afr J SM 2013;25:8-11.

137 Campbell PG, Peake JM, Minett GM. The specificity of rugby union training sessions in preparation for match demands. Int J Sports Physiol Perform 2018;13:496-503.

138 White PE, Otago L, Saunders N, et al. Ensuring implementation success: how should coach injury prevention education be improved if we want coaches to deliver safety programmes during training sessions? Br J Sports Med 2014;48:402-3.

139 Leventhal H, Singer R, Jones S. Effects of fear and specificity of recommendation upon attitudes and behavior. J Pers Soc Psychol 1965;2:20-9.

140 Ross L, Nisbett R. The Person and the Situation: Perspectives of Social Psychology. London, United Kingdom: Pinter \& Martin Publishers, 2011.

141 Hertwig R, Grüne-Yanoff T. Nudging and boosting: steering or empowering good decisions. Perspect Psychol Sci 2017;12:973-86.

142 Hendricks S, Till K, Oliver JL, et al. Technical skill training framework and skill load measurements for the rugby union tackle. Strength Cond J 2018;40:44-59.

143 Kerr HA, Ledet EH, Ata A, et al. Does instructional video footage improve tackle technique? Int J Sports Sci Coach 2018;13:3-15.

144 Stokes D. Pasteur's Quadrant: Basic Science and Technological Innovation. Brookings Institution Press, 2011.

145 Jakoet I, Noakes TD. A high rate of injury during the 1995 Rugby World Cup. S Afr Med J 1997;87:45-7.

146 Targett SG. Injuries in professional rugby union. Clin J Sport Med 1998;8:280-5.

147 Doyle C, George K. Injuries associated with elite participation in women's rugby over a competitive season: an initial investigation. Physical Therapy in Sport 2004;5:44-50.

148 Brooks JHM, Fuller CW, Kemp SPT, et al. A prospective study of injuries and training amongst the England 2003 Rugby World Cup squad. Br J Sports Med 2005;39:288-93.

149 Holtzhausen LJ, Schwellnus MP, Jakoet I, et al. The incidence and nature of injuries in South African rugby players in the rugby Super 12 competition. S Afr Med J 2006;96:1260-5.

150 Schick DM, Molloy MG, Wiley JP, et al. Women's Rugby World Cup. Br J Sports Med 2006;2008:447-51.

151 Fuller CW, Raftery M, Readhead C, et al. Impact of the International rugby board's experimental law variations on the incidence and nature of match injuries in southern hemisphere professional rugby union. S Afr Med J 2009;99:232-7.

152 Williams S, Trewartha G, Kemp SPT, et al. The influence of an artificial playing surface on injury risk and perceptions of muscle soreness in elite rugby union. Scand J Med Sci Sports 2016;26:101-8

153 Schwellnus MP, Jordaan E, Janse van Rensburg C, et al. Match injury incidence during the Super Rugby tournament is high: a prospective cohort study over five seasons involving 93641 playerhours. Br J Sports Med 2019;53:620-7.

154 Comstock RD, Fields SK. The fair sex? foul play among female rugby players. J Sci Med Sport 2005;8:101-10.
155 Schneiders AG, Takemura M, Wassinger CA. A prospective epidemiological study of injuries to new Zealand premier club rugby union players. Phys Ther Sport 2009;10:85-90.

156 Haseler CM, Carmont MR, England M. The epidemiology of injuries in English youth community rugby union. Br J Sports Med 2010;44:1093-9.

157 Archbold HAP, Rankin AT, Webb M, et al. RISUS study: rugby injury surveillance in Ulster schools. Br J Sports Med 2017;51:600-6.

158 Swain MS, Lystad RP, Henschke N, et al. Match injuries in amateur rugby union: a prospective cohort study - FICS Biennial Symposium Second Prize Research Award. Chiropr Man Therap 2016;24:1-8.

159 Leung FT, Franettovich Smith MM, Brown M, et al. Epidemiology of injuries in Australian school level rugby union. J Sci Med Sport 2017;20:740-4.

160 Sewry N, Verhagen E, Lambert M, et al. Trends in time-loss injuries during the 2011-2016 South African rugby youth weeks. Scand J Med Sci Sports 2018;28:2066-73.

161 Fuller CW, Taylor A, Molloy MG. Epidemiological study of injuries in international rugby sevens. Clin J Sport Med 2010;20:179-84.

115 Rizi RM, Yeung SS, Stewart NJ, et al. Risk factors that predict severe injuries in university rugby sevens players. J Sci Med Sport 2017;20:648-52.

163 Cruz-Ferreira AM, Cruz-Ferreira EM, Silva JD, et al. Epidemiology of injuries in Portuguese senior male rugby union sevens: a cohort prospective study. Phys Sportsmed 2018;46:255-61.

164 Duthie G, Pyne D, Hooper S. Time motion analysis of 2001 and 2002 Super 12 rugby. J Sports Sci 2005;23:523-30.

165 Deutsch MU, Kearney GA, Rehrer NJ. Time-Motion analysis of professional rugby union players during match-play. J Sports Sci 2006.

166 Eaton C, George K. Position specific rehabilitation for rugby union players. Part I: empirical movement analysis data. Physical Therapy in Sport 2006;7:22-9.

167 Quarrie KL, Hopkins WG. Changes in player characteristics and match activities in Bledisloe cup rugby union from 1972 to 2004. J Sports Sci 2007;25:895-903.

168 Roberts SP, Trewartha G, Higgitt RJ, et al. The physical demands of elite English rugby union. J Sports Sci 2008;26:825-33.

169 Austin D, Gabbett T, Jenkins D. The physical demands of Super 14 rugby union. J Sci Med Sport 2011;14:259-63.

170 van Rooyen KM. A statistical analysis of tackling performance during international rugby union matches from 2011. Int $\mathrm{J}$ Perform Anal Sport 2012;12:517-30.

171 Hendricks S, Roode B, Matthews B, et al. Defensive strategies in rugby union. Percept Mot Skills 2013;117:65-87.

172 Villarejo D, Palao JM, Toro EO. Match profiles for establishing position specific rehabilitation for rugby union players. Int $J$ Perform Anal Sport 2013;13:567-71.

173 van Rooyen M, Yasin N, Viljoen W. Characteristics of an 'effective' tackle outcome in Six Nations rugby. Eur J Sport Sci 2014;14:123-9.

174 Lindsay A, Draper N, Lewis J, et al. Positional demands of professional rugby. Eur J Sport Sci 2015;15:480-7.

175 Villarejo D, Palao J-M, Ortega E, et al. Match-related statistics discriminating between playing positions during the men's 2011 Rugby World Cup. Int J Perform Anal Sport 2015;15:97-111.

176 Brown JC, Boucher SJ, Lambert M, et al. Non-sanctioning of illegal tackles in South African youth community rugby. J Sci Med Sport 2018;21:631-4.

177 Suarez-Arrones L, Arenas C, López G, et al. Positional differences in match running performance and physical collisions in men rugby sevens. Int J Sports Physiol Perform 2014;9:316-23.

178 Ross A, Gill ND, Cronin JB. A comparison of the match demands of international and provincial rugby Sevens. Int J Sports Physiol Perform 2015;10:786-90.

179 Ross A, Gill N, Cronin J. The match demands of international rugby sevens. J Sports Sci 2015;33:1035-41. 